\title{
Pulmonary adiaspiromycosis: report of two cases
}

\author{
Adiaspiromicose pulmonar: relato de dois casos \\ Vitorino Modesto dos Santos ${ }^{14}$, Marcelo Cunha Fatureto², \\ João Carlos Saldanha ${ }^{3}$ and Sheila Jorge Adad ${ }^{34}$
}

\begin{abstract}
Two cases of human pulmonary adiaspiromycosis are reported. Patients were 29 and 54-year-old males, farm workers, with "grippe-like" symptoms and radiographic findings suggestive of granulomatous interstitial disease. Transthoracoscopic and transbronchial biopsies were performed. Pulmonary function was measured by spirometry. One patient used ketoconazole. Possibility of misdiagnosed pulmonary adiaspiromycosis is emphasized.
\end{abstract}

Key-words: Pulmonary mycosis. Adiaspiromycosis. Emmonsia parva var crescens. Chrysosporium parvum var crescens. Pulmonary biopsy. Spirometry.

Resumo Relatam-se casos de adiaspiromicose pulmonar em homens brancos de 29 e 54 anos, lavradores, com sintomas "gripais" e achados radiológicos sugestivos de doença granulomatosa intersticial. Biópsias transbrônquicas e transtoracoscópicas foram realizadas. A função pulmonar foi avaliada por espirometria. Um paciente usou cetoconazol. Enfatizam-se possibilidades de confusão diagnóstica na adiaspiromicose pulmonar.

Palavras-chaves: Micoses pulmonares. Adiaspiromicose. Emmonsia parva var crescens. Chrysosporium parvum var crescens. Biópsia pulmonar. Espirometria.

\begin{abstract}
Adiaspiromycosis is a rare pulmonary disease described in humans. It is a common fungal infection of lower order mammals, most usually wild rodents, with wide geographical distribution. This disease is caused by a geophilic fungus, Emmonsia parva var crescens ${ }^{14}{ }^{18}$, whose dustborne mycelial phase (conidia) may be accidentally inhaled and produce a perifocal granulomatous inflammatory reaction in the lungs ${ }^{14}$. In immunocompetent patients, fungus dissemination to extra pulmonary sites has not been reported 810111719 . Adiaconidia are spherical and do not replicate, but million fold increase in volume (diameter from 2.5 to $700 \mathrm{~mm})^{2} 920$, compress pulmonary parenchyma inducing an
\end{abstract}

intense inflammatory reaction, and soon degenerate and $\mathrm{die}^{18}$. Severity of lung lesions, clinical manifestations and pulmonary function changes will depend on the amount and distribution of inhaled conidia ${ }^{2027}$, associated diseases, fungus antigenicity ${ }^{1}$ and host immune response. The disease may be cured without treatment ${ }^{18}$, even the disseminated pulmonary form, which sometimes causes death ${ }^{19} 21$.

We report two cases of this unusual deep mycosis that would correspond to the $19^{\text {th }}$ and $20^{\text {th }}$ cases described in Brazil ${ }^{18}$. Similar to our previous report ${ }^{24}$, these cases were also diagnosed through transthoracoscopic lung biopsies performed at hospitals in Uberaba, MG.

\footnotetext{
1. Departamento de Clínica Médica. 2. Disciplina de Cirurgia Torácica; 3. Disciplina de Patologia Especial; 4 . Curso de Pós-graduação em Patologia da Faculdade de Medicina do Triângulo Mineiro (FMTM), Uberaba, MG.

Financial support: Fundação de Ensino e Pesquisa de Uberaba (FUNEPU).

Endereço para correspondência: Prof. Marcelo Cunha Fatureto. Disciplina de Cirurgia Torácica. Hospital Escola/FMTM. Av. Getúlio Guaritá s/n, 38057-020 Uberaba, MG.

e-mail: mfat@zaz.com.br

Recebido para publicação em 13/3/2000
} 


\section{CASE REPORTS}

Case 1. EB, a 54-year-old white male farm worker, natural from Arapuá, MG. Cigarette smoker (pack year: 25). Before admission, a chest x-ray film showed micronodular interstitial infiltration in both lungs (Figure 1) and for suspicious pneumonia he had used penicillin and gentamicin without any clinical or radiological improvement. On admission (09/27/97), he presented fever $\left(38^{\circ} \mathrm{C}\right)$, headache, myalgia, nausea and weight loss. Physical examination was otherwise normal. The routine laboratory tests were normal, except for leukocytosis $\left(13,500 / \mathrm{mm}^{3}\right)$ and neutrophilia (86\%). Spirometry showed severe restrictive disturbance, with forced vital capacity (FVC): 1,490ml (39.6\%, predicted: $3,760 \mathrm{ml})^{26}$. Thorax computerized tomography $(\mathrm{CT})$ revealed a diffuse interstitial micronodular infiltrate and septal lines suggestive of mycosis (Figure 1). Fiberoptic bronchoscopy was normal and neither mycobacteria nor fungus
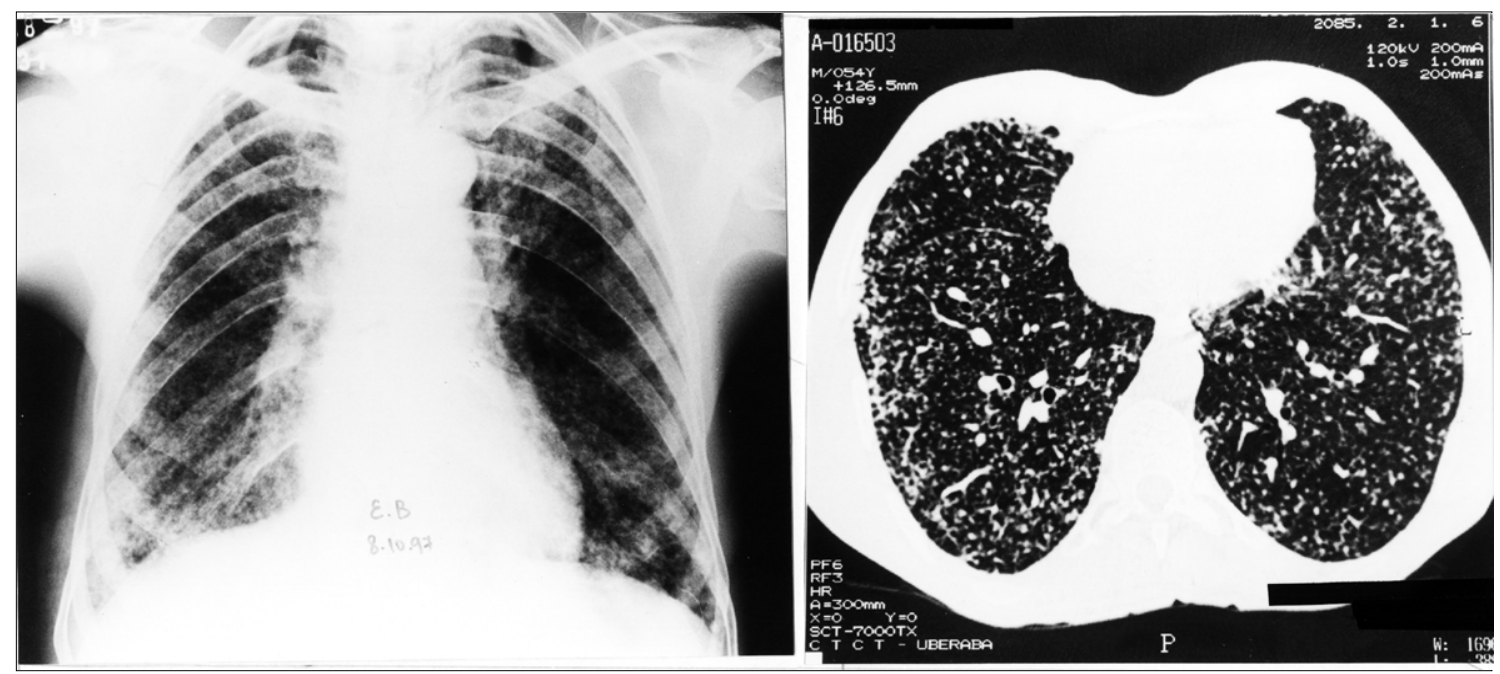

Figure 1 - Case 1 chest $x$-ray and CT, showing diffuse and bilateral micronodular interstitial and linear septal infiltrate.

were present in samples of the bronchoalveolar lavage aspirate or in the transbronchial biopsy material. On video assisted lung biopsy, the pleural surface appearance was normal; nevertheless, the histopathological study revealed pulmonary adiaspiromycosis. Microscopically, there was an intense chronic inflammatory reaction in the alveolar tissue, with mixed granulomas development. Granulomas were characterized by a lymphocytic and plasmacytic infiltrate surrounded by a palisade of histiocytes, and in whose center pathogenic microorganisms involved by neutrophils were observed (Figure 2). In some granulomas there was a necrotic center with abundant polimorphonuclear neutrophils, without evidence of the fungus. Adiaconidia were easily identified through their round or ovoid large size, the densely silver staining thick wall and the granular complex inner structure.

Patient used ketoconazole (200mg/day) during two months and, on 11/20/97 he was symptomless. Spirometry showed mild restrictive disturbance, with FVC: $2,520 \mathrm{ml}(67 \%$, predicted: $3,760 \mathrm{ml})^{26}$. In 02/05/98, spirometry was normal, with FVC: $3,230 \mathrm{ml}(85.9 \% \text {, predicted: } 3,760 \mathrm{ml})^{26}$. In 06/18/98, he had no complaints, with body mass index: $20.78 \mathrm{~kg} / \mathrm{m}^{2}$, normal blood counts and normal spirometry results. Comparatively, the chest $\mathrm{x}$-ray and CT films showed less intense granular interstitial infiltrate and interlobular septal lines (Figure 3).

Case 2. HPC, a 29-year-old white male farm worker, natural from São Gotardo, MG. Cigarette smoker (pack year: 18). Before admission, a chest x-ray film showed bilateral miliary pulmonary 
infiltration and he had received rifampin $600 \mathrm{mg} /$ day, isoniazid $400 \mathrm{mg} /$ day and pyrazinamide $2 \mathrm{~g} /$ day. On admission (12/22/97), he was complaining of fever $\left(38.5^{\circ} \mathrm{C}\right)$, dry cough, right anterior pleural

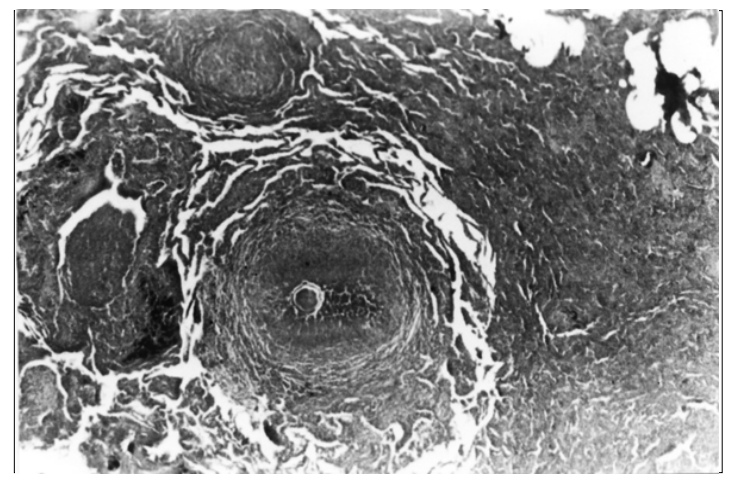

Figure 2 - Case 1 photomicrography showing mixed granulomas, the largest containing a central adiaconidium, surrounded by polymorphonuclear neutrophils, a palisade of macrophages and a lymphocytic and plasmacytic halo. Some granulomas without evidence of adiaconidia are observed. (HE, 40X).

and neutrophilia ( $82 \%)$, routine laboratory tests were normal. Chest $x$-ray films showed bilateral diffuse interstitial micronodular infiltrate (Figure 4).

Fiberoptic bronchoscopy was normal. The middle lobe transbronchial biopsy revealed granulomas containing epithelioid histiocytes surrounded by lymphocytes, rare eosinophils and

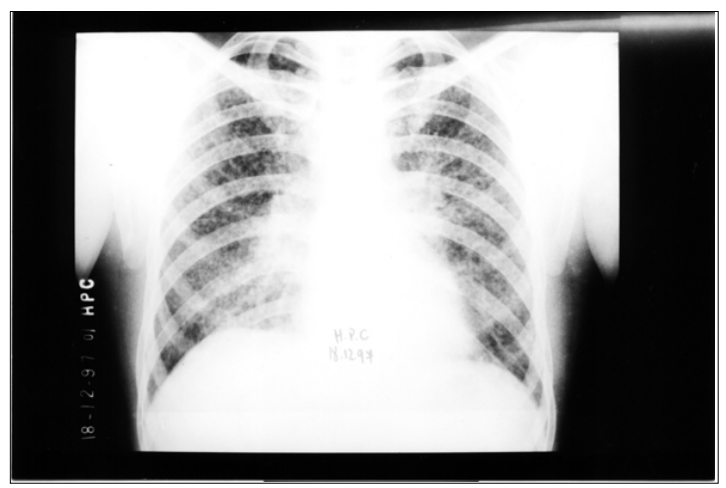

Figure 4 - Case 2 chest x-ray revealing diffuse and bilateral micronodular interstitial infiltrate. pain, breathlessness with exercise and weight loss. Physical examination disclosed mild anemia, respiratory rate $36 / \mathrm{min}$, dry rales and wheezing in both lungs. Except for leukocytosis $\left(12,300 / \mathrm{mm}^{3}\right)$

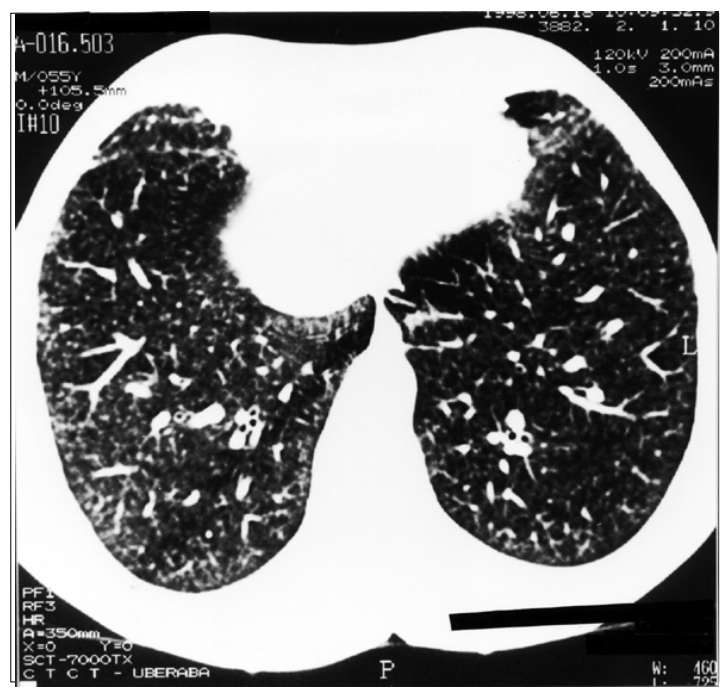

Figure 3 - Case 1 control chest CT revealing regression of the interstitial and septal infiltrate.

fibrosis. Centrally located in a granuloma, there was a periodic acid Schiff (PAS) positive spherical structure with a trilaminar wall, containing a granular eosinophilic material, morphologically compatible with the diagnosis of pulmonary adiaspiromycosis (Figure 5). The transthoracoscopic pulmonary biopsy showed a round structure limited by two walls, the outer deeply eosinophilic

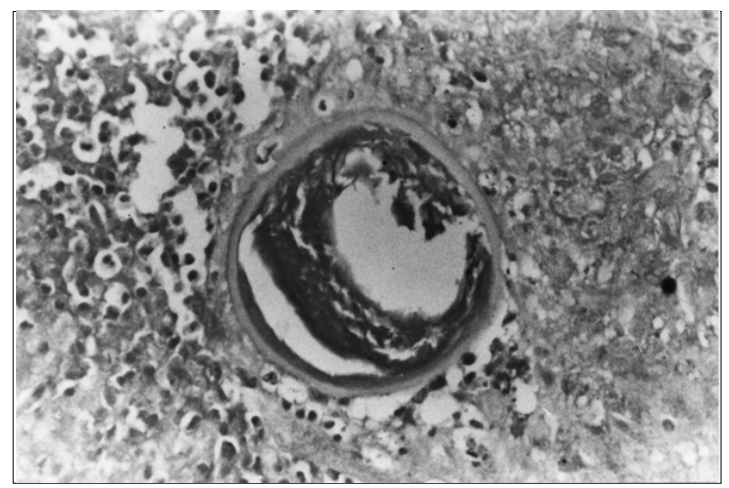

Figure 5-Adiaconidium in granuloma center, with periodic acid Schiff positive trilaminar wall and containing eosinophilic granular material (PAS, 400X). 
and the inner not stained by eosin, centrally empty and surrounded by a fibrogranulomatous response with Langhans' giant cells, aspect compatible with Emmonsia parva var crescens. No mycobacteria or fungi were cultured from the samples obtained from bronchoalveolar lavage aspirate and from pulmonary tissue.
Patient was followed up in the outpatient service and did not use the prescribed ketoconazole. On 08/27/98, he was in a good health, and spirometry showed a mild restrictive disturbance with FVC: $4,020 \mathrm{ml}(82.7 \% \text {, predicted } 4,860 \mathrm{ml})^{26}$. The chest $x$-ray and CT films showed a clear improvement of the pulmonary lesions, and only a very discrete micro nodular infiltrate was observed (Figure 6).
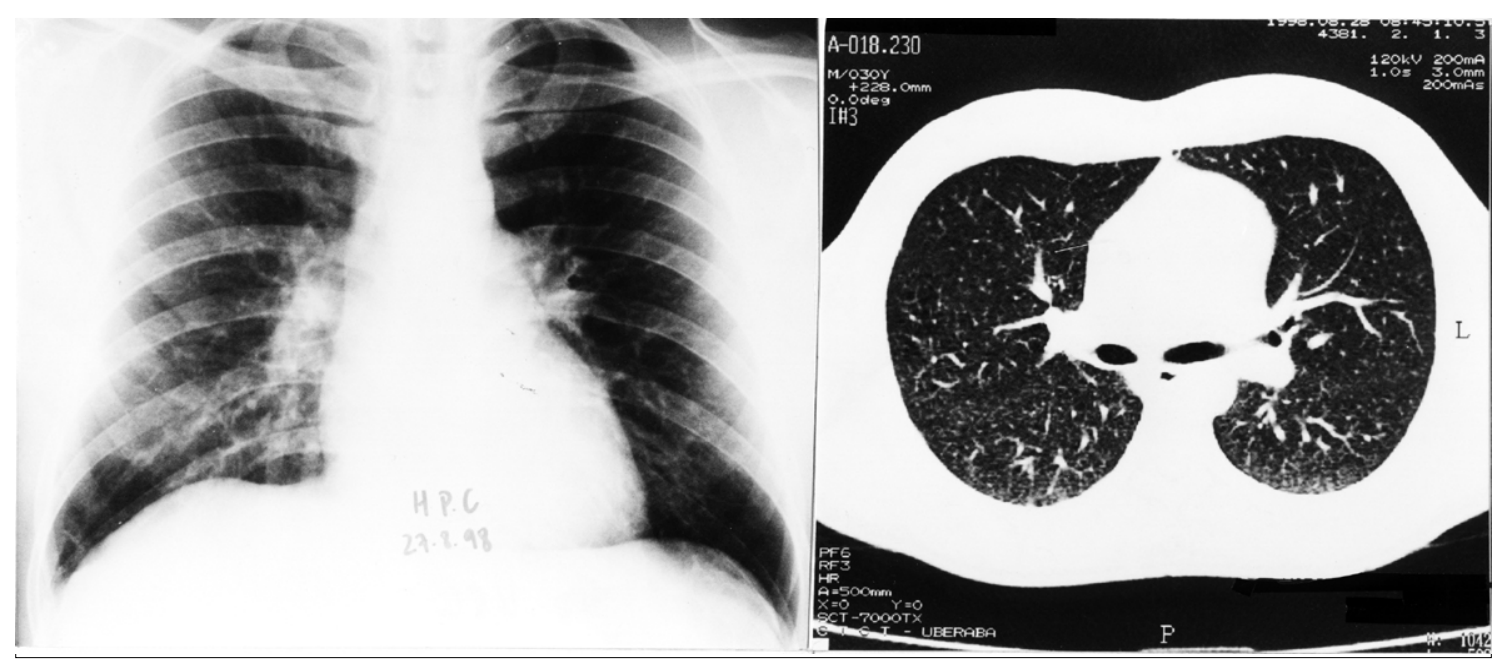

Figure 6 - Case 2 control chest $x$-ray and CT showing only a very discrete micronodular infiltrate.

\section{DISCUSSION}

As demonstrated in Table 1, which includes a case previously reported by the authors ${ }^{24}$, all the patients were farm workers engaged in outdoor activities exposed to dust and, therefore, at risk of Emmonsia conidia inhaling. In our cases, clinical complaints started from August to December, which is a period characterized by warm dry climate and high winds ${ }^{19}$. Two of the patients were cigarette smokers. There was no evidence of associated diseases nor immunosuppression. All the patients referred grippe-like symptoms and, due to pulmonary lesions radiographic appearance, they had been treated for atypical pneumonia or miliary tuberculosis. Leukocytosis, neutrophilia and pulmonary reticular and micronodular infiltrate were observed in all the cases. Patients lung function was measured by spirometry, and revealed moderate to severe restrictive disturbances which, without apparent functional sequelae, returned to normality concomitant with the patients clinical cure, about a month later.

Table 1 - Comparative data from three cases of pulmonary adiaspiromycosis diagnosed in Uberaba, MG, from August 94 to December 97.

\begin{tabular}{lllccccc}
\hline Patients & Date & Profession & Chest $x$-ray & ttc biopsy & tbr biopsy & Azole & Evolution \\
\hline BGO, m, w, 26y & Aug, 94 & farm worker & miliary & positive & negative & yes & cure \\
EB, m, w, 54y & Sept, 97 & farm worker & miliary & positive & negative & yes & cure \\
HPC, m, w, 29y & Dec, 97 & farm worker & miliary & positive & positive & no & cure \\
\hline
\end{tabular}

m: male; w: white; y: years; ttc: transthoracoscopic; tbr: transbronchial; azole: ketoconazole. 
On the contrary to other reports ${ }^{318}$, transbronchial biopsy was less useful than transthoracoscopic biopsy to render a specific diagnosis of pulmonary adiaspiromycosis in our patients. Both procedures were performed in all the cases, however, only in case 2 the lung tissue samples obtained via transbronchial revealed the presence of adiaconidia 6121524 .

In the present cases, an azole compound was prescribed to patients with the pulmonary disseminated form of disease 202124 . Although one of these did not use the drug prescribed, both cases similarly improved very well within a month, favoring the possibility of spontaneous regression of the pulmonary lesions, even in cases of symptomatic disseminated disease.

The etiologic agent of adiaspiromycosis belongs to class Hyphomycetes, genus Emmonsia or Chrysosporium related to Ajellomyces, family Onygenaceae, including Blastomyces dermatitides and Histoplasma capsulatum ${ }^{571625}$. Fungi pertaining to the genus Chrysosporium have been described in samples from soil and lung tissue of burrowing mammals ${ }^{23}$, especially rodents, in wild and urbanperipheric areas, with a world-wide-distribution ${ }^{1322}$.

It is well known that farm activities may expose humans to soil dust containing conidia fungus; however, case reports of symptomatic human adiaspiromycosis or incidental necropsy findings persist astonishingly rare, even in countries where unhealthy agricultural and rural activities still predominate. It is possible that this infection may be more frequent than reported, with a subclinical evolution, besides being misdiagnosed as grippe, pneumonia, miliary tuberculosis, another mycosis and conditions causing reticular and nodular lung infiltration.

Factors that may impede the diagnosis of human pulmonary adiaspiromycosis include very limited knowledge about this disease, asymptomatic infections or non specific clinical manifestations, chest $\mathrm{x}$-ray appearance similar to other pulmonary diseases, lack of a specific serologic test, culture of the fungus not available, inadequate lung tissue samples, and the possibility of spontaneous cure in almost all cases.

\section{REFERENCES}

1. Albassam MA, Bhatnagar R, Lillie LE, Roy L. Adiaspiromycosis in striped skunks in Alberta, Canada. Journal of Wildlife Diseases 22:13-18, 1986.

2. Barbas Filho JV, Amato MB, Deheinzelin D, Saldiva $\mathrm{PH}$, Carvalho CR. Respiratory failure caused by adiaspiromycosis. Chest 97:1171-1175, 1990.

3. Barbosa AA, Lemos ACM, Severo LC. Acute pulmonary adiaspiromycosis. Report of three cases and a review of 16 other cases collected from the literature. Revista Iberoamericana de Micología 14:177-180, 1977.

4. Bensard DD, Mclntyre Jr RC, Waring BJ, Simon JS. Comparison of video thoracoscopic lung biopsy to open lung biopsy in the diagnosis of interstitial lung disease. Chest 103:765-770, 1993.

5. Bowman BH, White TJ, Taylor JW. Human pathogenetic fungi and their close nonpathogenic relatives. Molecular Phylogenetics and Evolution 6:89-96, 1996.

6. Cazzadori A, Di Pieri G, Todeschini G, Boschiero L, Perona G, Concia E. Transbronchial biopsy in the diagnosis of pulmonary infiltrates in immunocompromised patients. Chest 107:101-106,1995.

7. Chabasse D. Taxonomic study of keratiniphilic fungi isolated from soil and some mammals in France. Mycopathologia 101:133-140, 1988.

8. Echavarria E, Cano EL, Restrepo A. Disseminated adiaspiromycosis in a patient with AIDS. Journal of Medical and Veterinary Mycology 31: 91-97, 1993.
9. Emmons CW, Ashburn LL. The isolation of Haplosporangium parvum and Coccidioides immitis from wild rodents. Their relationship to coccidioidomycosis. Public Health Reports 57:1715-1727, 1942.

10. Emmons CW, Jellison WL. Emmonsia crescens and adiaspiromycosis (Haplomycosis) in mammals. Annals New York Academy of Sciences 89:91-101, 1960.

11. England DM, Hochholzer L. Adiaspiromycosis: an unusual fungal infection of the lung. Report of 11 cases. The American Journal of Surgical Pathology 17:876-886, 1993.

12. Ferson PF, Landreneau RJ, Dowling RD, Hazelrigg SR, Ritter P, Nunchuck S, Perrino MK, Bowers CM, Mack MJ, Magee MJ. Comparison of open versus thoracoscopic lung biopsy for diffuse infiltrative pulmonary disease. Journal of Thoracic Cardiovascular Surgery 106:194-196, 1993.

13. Hubalek Z, Nesvadbova J, Halouzka J. Emmonsiosis of rodents in an agroecosystem. Medical Mycology 36: 387390, 1998.

14. Kodousek R, Vortel V, Fingerland A, Vojtek V, Sery Z, Hajek V, Kucera K. Pulmonary adiaspiromycosis in man caused by Emmonsia crescens: report of a unique case. American Journal of Clinical Pathology 56:394-399, 1971.

15. Krasna MJ, White CS, Aisner SC, Templeton PA, McLaughlin JS. The role of thoracoscopy in the diagnosis of interstitial lung disease. Annals of Thoracic Surgery 59:348-351, 1995. 
16. Leclerc MC, Philippe H, Guého E. Phylogeny of dermatophytes and dimorphic fungi based on large subunit ribosomal RNA sequence comparisons. Journal of Medical and Veterinary Mycology 32:331-341, 1994.

17. Levy FE, Larson JT, George E, Maisel RH. Invasive chrysosporium infection of the nose and paranasal sinuses in an immunocompromised host. OtolaryngologyHead and Neck Surgery 104:384-388, 1991.

18. Lima TSM, Moraes MAP, Magalhães HQ, Athayde NSG. Novo caso de adiaspiromicose humana diagnosticado por biópsia transbrônquica. Jornal de Pneumologia 24:339-341, 1998.

19. Moraes MAP, Almeida MC, Raick AN. Caso fatal de adiaspiromicose pulmonar humana. Revista do Instituto de Medicina Tropical de São Paulo 31:188-194, 1989.

20. Moraes MAP, Silva AE, Raick AN. Adiaspiromicose pulmonar humana. Novo caso da forma disseminada. Revista da Sociedade Brasileira de Medicina Tropical 23:171-174, 1990.

21. Peres LC, Figueiredo F, Peinado M, Soares FA. Fulminant disseminated pulmonary adiaspiromycosis in humans. The American Journal of Tropical Medicine and Hygiene 46:146-150, 1992.
22. Piontelli E, Toro SM MA, Casanova D. Latitudinal distribution of onygenales and related hyphomycetes in soils of northern Chile between $18-34^{\circ}$ south latitude. Boletín Micológico 5: 79-106, 1990.

23. Santos VM. Comportamento em cultura e diagnóstico morfológico de Emmonsia crescens em tatus. Revista da Sociedade Brasileira de Medicina Tropical 32:307, 1999.

24. Santos VM, Santana JH, Adad SJ, Lopes GP, Fatureto MC. Adiaspiromicose pulmonar disseminada. Relato de caso. Revista da Sociedade Brasileira de Medicina Tropical 30:397-400, 1997.

25. Sigler L. Ajellomyces crescens sp nov, taxonomy of Emmonsia spp, and relatedness with Blastomyces dermatitidis (teleomorph Ajellomyces dermatitidis). Journal of Medical and Veterinary Mycology 34:303-314, 1996.

26. Sociedade Brasileira de Pneumologia e Tisiologia. I Consenso Brasileiro sobre Espirometria. Jornal de Pneumologia 22:105-164, 1996.

27. Teixeira AA, Moraes RC, Magalhães HQ, Bumbieris ES. Adiaspiromicose pulmonar granulomatosa disseminada. Radiologia Brasileira 24:121-126, 1991. 